\title{
Tumour-associated carbohydrate antigens in breast cancer
}

\author{
Aurélie Cazet',2, Sylvain Julien², Marie Bobowski,2, Joy Burchell ${ }^{3}$ and Philippe Delannoy ${ }^{1,2 *}$
}

\begin{abstract}
Glycosylation changes that occur in cancer often lead to the expression of tumour-associated carbohydrate antigens. In breast cancer, these antigens are usually associated with a poor prognosis and a reduced overall survival. Cellular models have shown the implication of these antigens in cell adhesion, migration, proliferation and tumour growth. The present review summarizes our current knowledge of glycosylation changes (structures, biosynthesis and occurrence) in breast cancer cell lines and primary tumours, and the consequences on disease progression and aggressiveness. The therapeutic strategies attempted to target tumour-associated carbohydrate antigens in breast cancer are also discussed.
\end{abstract}

\section{Introduction}

Glycosylation is one of the most important modifications of proteins and lipids. The structure of glycans is highly diversified and their biosynthesis requires specific enzymatic machinery involving a high number of glycosyltransferases. Glycoconjugates of the cell surface are thought to play important roles in a variety of biological functions, such as cell-cell and cell-substrate interactions, bacterial adhesion, membrane organization, cell immunogenicity and protein targeting. For example, sialyl-Lewis ${ }^{x}\left(\right.$ sLe $\left.^{\mathrm{x}}\right)$ antigens are the ligands for selectins and are involved in the recruitment of leukocytes to lymphoid tissues and inflammation sites [1].

Glycan structures depend on the cell type, developmental stage and cell differentiation, and are modified in many pathologic states including cancers. The modification of cellular glycosylation is indeed a common phenotypic change of cancer cells that mainly affects the

*Correspondence: philippe.delannoy@univ-lille1.fr

'Structural and Functional Glycobiology Unit, UMR CNRS 8576, University of

Sciences and Technologies of Lille, 59655 Villeneuve d'Ascq, France

Full list of author information is available at the end of the article outer part of glycans, leading to the expression of tumour-associated carbohydrate antigens (TACAs). Increased $\beta 1,6$-branching, increased sLe $^{\mathrm{x}}$ or sialyl-Lewis ${ }^{\mathrm{a}}$ $\left(\mathrm{sLe}^{\mathrm{a}}\right)$ antigens, or the general increase in sialylation are commonly observed in $\mathrm{N}$-linked and $\mathrm{O}$-linked glycans of carcinoma cells and are associated with grade, invasion, metastasis and poor prognosis. These changes in glycosylation often reflect a deregulation of glycosyltransferase expression at the transcriptional level, and several examples have shown that glycosyltransferase genes, including ST6GAL1 [2] and MGAT5 [3], are regulated by oncogenes.

$\mathrm{sLe}^{\mathrm{x}}, \mathrm{s}-\mathrm{Le}^{\mathrm{a}}$ and sialyl-Thomsen-nouvelle (sTn) are tumour-associated antigens found in breast cancer [4-6]. When these antigens are detected at the surface of breast carcinoma cells, they are usually associated with a poor prognosis and a reduced overall survival of the patients [7]. These glycosylation changes mostly result from the modification of the expression of glycosyltransferase (GT) genes, and the level of expression of sialyltransferases has been proposed as a prognostic marker for the follow-up of breast cancer patients $[8,9]$.

Several cellular models have been developed in order to explain the mechanisms by which carbohydrate antigens can reinforce breast cancer progression and aggressiveness, showing the implication of TACAs in cell adhesion, migration, proliferation and tumour growth $[10,11]$. TACAs such as sTn are also targets for breast cancer immunotherapy. Finally, recent data seem to indicate an important role of complex gangliosides in breast cancer progression and metastasis [12,13]. The present review summarizes our current knowledge of glycosylation changes that occur in breast cancer and the consequences of these changes on disease development and aggressiveness.

\section{Defects in mucin-type $O$-glycosylation}

One of the hallmarks of breast adenocarcinomas is the overexpression and aberrant localization of membranebound mucins, such as MUC1 and MUC4 [14]. Mucins are characterized by a large number of tandem repeated domains, rich in serine and threonine, which are therefore densely $O$-glycosylated. 
$O$-glycans expressed by normal breast epithelial cells are composed of Core2 structures extended with a linear polylactosaminic chain, which can be fucosylated or sialylated [15] (Figure 1). Accordingly, a recent study reported a prevalence of $\mathrm{Le}^{\mathrm{x}}$ expression at the apex of normal breast epithelia, where MUC1 is also detected [16].

In contrast, breast cancer cell lines express truncated $O$-glycans with shorter polylactosaminic chains and a tendency to switch from Core $2 \mathrm{O}$-glycans to sialylated or unsialylated Core1 structures (Figure 1) [17]. It has long been known that breast cancer tissues contain more sialic acid and more sialyltransferase activity [18] than corresponding normal tissues. Breast cancer cells may thus express shorter $O$-glycans due to premature sialylation of the polylactosaminic chain blocking further extension, or due to truncation of the $O$-glycans at the core level owing to the sialylation of the Core 1 structure or of the initial GalNAc, leading to the expression of sialylThomsen-Friedenreich (sialyl-T) antigen structures and sTn antigen, respectively (Figure 1).

Alternatively, a defect in GTs that are involved in the biosynthesis of the $O$-glycan cores can also lead to the incomplete synthesis of the glycans, allowing the expression of $O$-linked carbohydrate antigens known as Thomsen-Friedenreich ( $\mathrm{T}$ or $\mathrm{TF}$ ) antigen (unsialylated Core1) and Thomsen-nouvelle (Tn) antigen (initial unsubstituted GalNAc) (Figure 1).

\section{Thomsen-Friedenreich antigen}

$\mathrm{T}$ antigen is the cryptic precursor of Core $2 \mathrm{O}$-glycans, which can be unmasked if the cancer cells lose their ability to synthesize Core2 (Figure 1). T antigen consists of unsialylated Core1 structures (Gal $\beta 1$-3GalNAc $\alpha$ Ser/ Thr) initially described on glycophorins of red blood cells. The galactose residue is crucial for the antigenicity since re-sialylation or $\beta$-D-galactosidase treatment abrogates T-antigen detection [19].

Georg Springer was the pioneer of the study of $\mathrm{T}$ antigen in breast cancer. Using natural anti- $T$ antisera, he first showed that all breast cancers, but not benign lesions or normal mammary gland, expressed the $\mathrm{T}$ antigen [20]. Later studies using monoclonal antibodies demonstrated the presence of $\mathrm{T}$ antigen at a low level in normal epithelium or metaplastic lesions of the breast [21].

Lectins such as Arachis hypogea agglutinin/peanut lectin (PNA), Amaranthus caudatus lectin or Artocarpus integrifolia/jacalin have been extensively used to detect $\mathrm{T}$ antigen. None of these lectins, however, is exclusively specific for the Gal $\beta 1-3 G$ alNAc structure. Both $A$. caudatus agglutinin and $A$. integrifolia agglutinin/jacalin are specific for GalNAc when there is no substitution on C6 of the saccharide (Figure 2). In contrast, substitution on $\mathrm{C} 3$ does not impair their binding. Consequently both $A$. caudatus agglutinin and A. integrifolia agglutinin/ jacalin can bind to Tn antigen (GalNAca-Ser/Thr), T antigen (Gal $\beta 1$-3GalNAc $\alpha$-Ser/Thr) and sialyl-T antigen (Neu5Ac $\alpha 2-3 G a l \beta 1-3 G a l N a c \alpha-S e r / T h r)[22,23]$.

PNA is specific for unsubstituted Gal residues [24]. Because of its high reactivity with asialo-glycophorin, PNA has been tagged as the anti-T lectin [24]. PNA was able to react weakly with healthy tissue while anti-T antisera were not, however, suggesting that PNA specificity was slightly wider than the sole $\mathrm{T}$ carbohydrate. Indeed, PNA can bind, albeit with lower affinity, to terminal galactose in a variety of glycans including glycolipids such as asialo- $\mathrm{G}_{\mathrm{M} 1}$ [23] or $N$-acetyl-lactosamine (LacNAc) [25]. Studies of T-antigen expression using PNA should therefore be treated cautiously, especially in the absence of complementary analysis of the $O$-glycosylation of the considered cells or tissues.

In parallel to lectins, mAbs have long been used to investigate $\mathrm{T}$-antigen expression in epithelial cancers [26]. As for lectins, most mAbs are not strictly specific for the sole Galß1-3GalNAc-Ser/Thr structure - some of them, such as A78-G/A7, cross-reacting with asialo- $\mathrm{G}_{\mathrm{M1}}$. Other mAbs define site-specific $\mathrm{T}$ antigens, such as BW835 with the VTSA motif in MUC1 tandem repeat. The HH8 mAb, as PNA, tolerates further substitution on the C6 of the GalNAc leading to Core2 structures [26] (Figure 2).

These subtle differences of specificity concur with the variability of the detection of $\mathrm{T}$ antigen in tumour tissues $[26,27]$, and these discrepancies have fuelled debates regarding the prognosis value of $\mathrm{T}$-antigen expression in breast cancers. PNA staining does not have any prognostic significance [26], while a more recent study using the mAb A78-G/A7 showed a correlation of T-antigen expression with a better prognosis [28], opposite to what is reported for gastrointestinal, lung or cervix cancers.

A recent study has shown that $98 \%$ of the disseminated tumour cells in the bone marrow were positively stained by a new anti-T antibody [29], suggesting a role for $\mathrm{T}$ antigen in the metastasis process. This putative role has been investigated during the past decade, on the assumption that Galß1-3GalNAc-R disaccharide could be a good ligand for Galectin-3 [30], which has been shown to promote breast cancer metastasis by mediating adhesion to endothelial cells. Although Galectin-3 seems to be involved in breast cancer metastasis through its interaction with some cancer-associated O-glycans [31], however, the nature of its ligand remains to be clearly elucidated via a comprehensive characterization of the glycosylation pattern required for this interaction.

To summarize, there is strong evidence showing that $\mathrm{T}$ antigen is frequently overexpressed in breast cancer, suggesting that the changes in $\mathrm{O}$-glycosylation provide some advantage to the tumour development. Relation to prognosis or metastatic behaviour, however, suffers from 


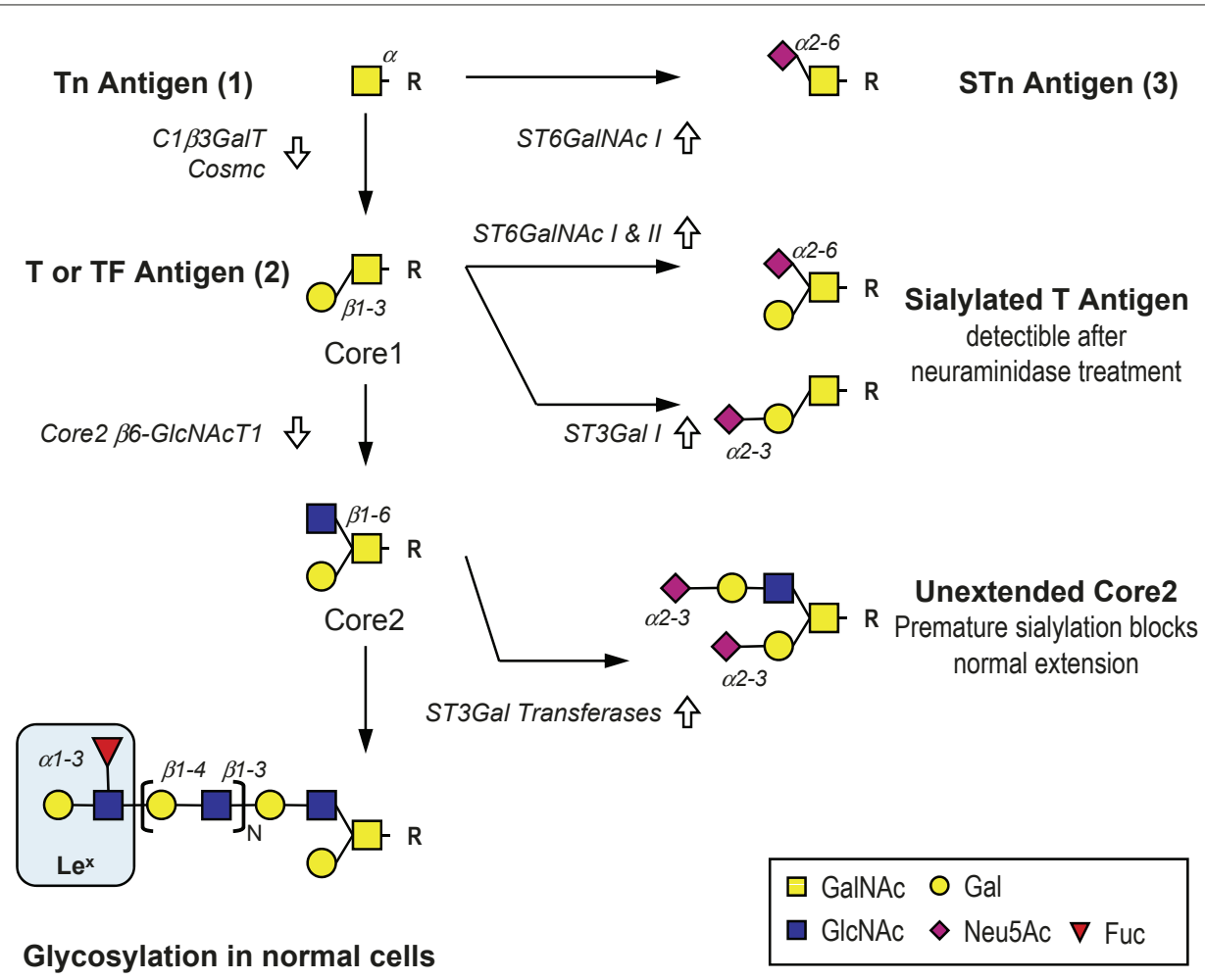

Figure 1. Pathways of biosynthesis of $O$-glycans in normal and cancer breast epithelial cells. All of these transfer reactions are catalysed in the Golgi apparatus. Enzymes involved in the pathways are indicated in italic font next to the arrows. Various mechanisms are illustrated by which O-glycans expressed in normal cells (bottom left) can be turned down to shorter and sialylated species. First, the enzymes involved in extended O-glycans can be downregulated or mutated (downward white arrows) in cancer cells, leading to a decrease or an absence of extended structures and revealing previously masked precursors such as T and Tn antigens. Alternatively or concomitantly, overexpression of diverse sialyltransferases (upward white arrows) can compete with the enzymes of normal extension and generate truncated sialylated structures (right column). This competition can occur at different levels of the extension pathway and produce the sialylated structures of each precursor (that is, sialyl-Thomsen-nouvelle (STn) antigen, sialyl-Thomsen-Friedenreich (sialyl-T or sialyl-TF) antigen (or sialylated Core1) and sialylated Core2 O-glycans). Gal, Galactose, GalNAc, N-acetylgalactosamine; GlcNAc, N-acetylglucosamine; Neu5Ac, N-acetylneuraminic acid; Fuc, fucose. Linkages (anomery and carbons involved) are only indicated the first time they appear along the pathway. N, various numbers (2 to 10) of repeats of lactosamine units (Gal $\beta 1-3 / 4 G \mid c N A c)$.

contradictory studies - partially due to the use of different probes - and remains to be unambiguously demonstrated.

\section{Thomsen-nouvelle antigen}

Tn antigen is the cryptic precursor of the $\mathrm{T}$ antigen (Core1) that can be unmasked if a cell loses its ability to synthesize the Core1 structure (see Figure 1).

Tn (GalNAc $\alpha-\mathrm{R})$ expression on blood cells is responsible for Tn syndrome, which is a rare autoimmune haematological disorder [32]. Tn syndrome occurs due to mutations in the COSMC gene coding the C1ß3GalTspecific molecular chaperone, leading to a drastic decrease of C1ß3GalT (T-synthase) activity [33]. Mutations and loss of heterozygosity of COSMC were described in colon cancer and melanoma cancer Tn-positive cells, as well as in tissues from two Tn-positive cervical cancers [34]. Extensive studies of COSMC in epithelial cancers, however, showed that these events were rare and could only partially explain Tn expression in cancers [35].

A range of GalNAc-specific lectins, including Helix pomiata lectin (HPA) and plant lectins from Dolichos biflorus, Griffonia simplicifolia, Wistaria floribundia, Glycine max soybean, Vicia villosa isolectin B4 (VVA) and Salvia sclarea agglutinin, can be used to detect Tn antigen [32,36]. These lectins bind to terminal GalNAc and therefore react with Tn antigen, but also with Forssman antigen (GalNAc 1 1-3GalNAc $\beta-R)$ and to some extent with blood group A (GalNAc $\alpha 1-3[$ Fuc $\alpha 1-2]$ Gal $\beta-R)$ or glycolipids [36]. HPA, which has been extensively used to study Tn expression in breast cancer [37], has been shown by some authors to bind $\mathrm{T}$ antigen [36]. There is also a range of mAbs available to detect Tn antigen [32]. Some of them, however, can slightly cross-react with sTn.

Tn antigen was found to be expressed in almost $90 \%$ of breast cancers while it is barely detected in normal tissue 


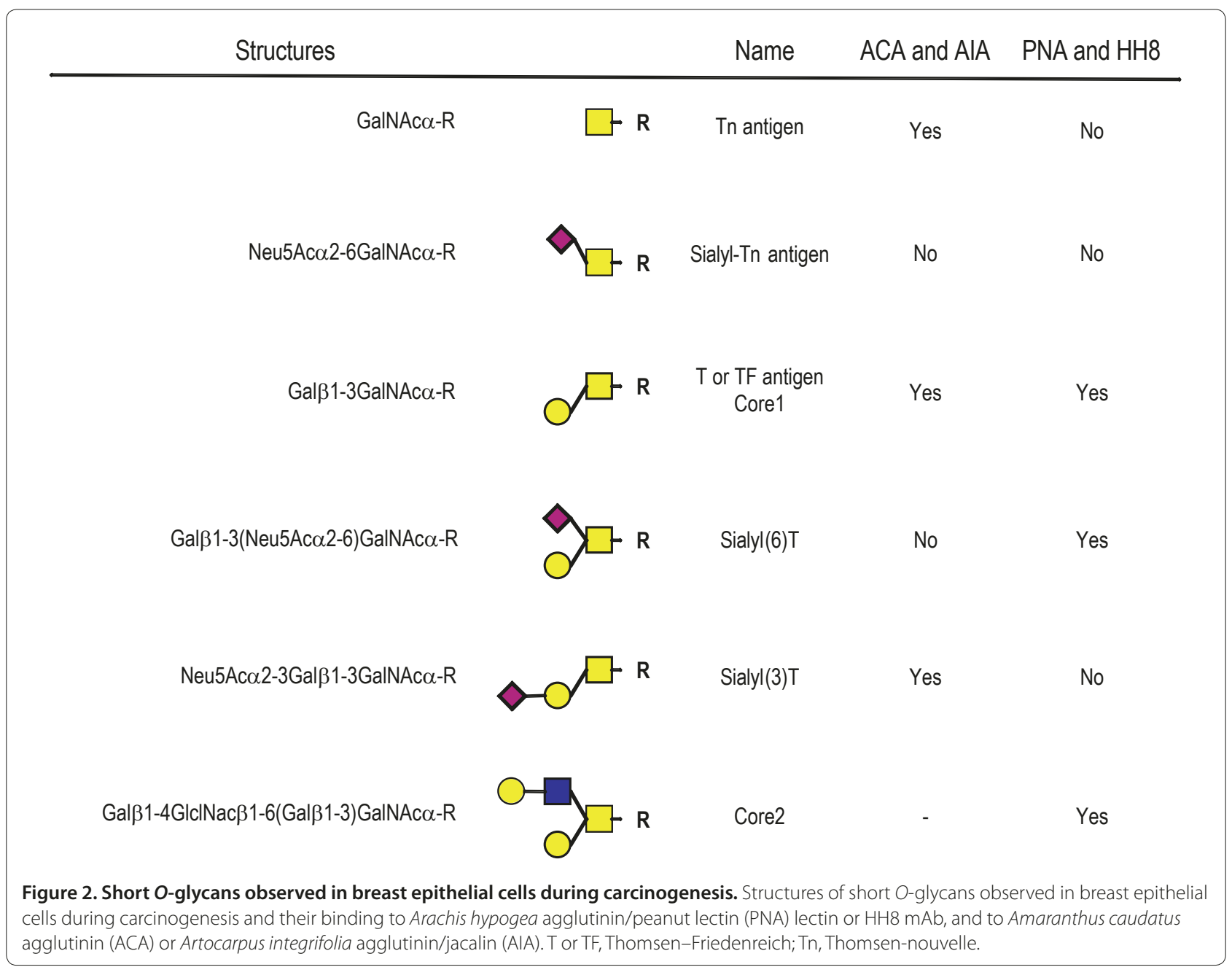

[38]. Association with high grade has been reported for invasive ductal carcinomas (IDC) using a pool of anti-Tn antibodies [39] and for ductal carcinoma in situ using VVA and G. simplicifolia agglutinin [40]. Using VVA, G. simplicifolia agglutinin and 83D4 mAb, other authors reported a tendency to lose Tn expression in grade III tumours [41]. Using either anti-Tn mAb or VVA, Tn was found associated with the Pathological Tumor-NodeMetastasis (pTNM) tumour stage in IDC $[39,42]$. Tn expression was also associated with decreased overall survival using antibodies [35] or HPA [43] and with increased risks of recurrence using VVA [42] or HPA [44].

Strikingly, Tn expression was always observed in lymph node metastatic cells using either mAb or lectins $[39,41]$ with $100 \%$ of Tn-positive metastatic cells, while primary tumours could exhibit various percentages of cell positivity $[39,41,42]$. Tn expression in primary tumours seems consistently associated with lymph node involvement using mAbs [41,42], HPA [43] or VVA [42], and even with invasion of lymphatic vessels within the primary tumour [42]. This observation strongly suggests that $\mathrm{Tn}$ antigen may play a role in the mechanism involved in lymph node metastasis. Indeed, Danussi and colleagues have recently shown that a newly generated anti-Tn antibody could block Tn-positive MCF-7 breast cancer cell line interaction with lymphatic endothelium of the mammary pad in an animal model [45]. A putative receptor(s) for Tn antigen in lymphatic cells, however, remains to be identified.

One known receptor for Tn antigen is the macrophage galactose-type lectin (MGL), which, in human, is specific for GalNAc [46]. MGL is expressed in immature dendritic cells and macrophages, and is proposed as an immunomodulatory receptor [46]. MGL has been shown to bind Tn antigen carried by MUC1 in colon carcinoma cells [47], and human immature dendritic cells can uptake MUC1-Tn peptide in a MGL-mediated way [48]. The MGL-Tn interaction, however, has not yet been investigated regarding its possible functional involvement in breast cancer development. 


\section{Sialyl-Thomsen-nouvelle antigen}

Tn antigen can be sialylated at the C6 position of GalNAc, resulting in the disaccharide Neu5Ac 2 2-6GalNAc-R (sTn). STn is absent in normal healthy tissues but can be detected at various frequencies in almost all kinds of carcinomas [49].

ST6GalNAc I is the enzyme catalysing the transfer of sialic acid onto GalNAc in vivo [50]. It has been proposed that COSMC mutation was necessary to provide the Tn acceptor substrate for ST6GalNAc I to synthesize sTn antigen [34]. Transfection of ST6GalNAc I cDNA, however, has been shown to be sufficient to induce sTn expression in various breast cancer cell lines expressing Core1 and Core2 glycans $[11,50,51]$, proving that ST6GalNAc I can compete with active Core $1 \beta 1,3$-galactosyltransferase.

Several mAbs have been raised against sTn antigen using various immunogens, leading to subtle differences in the way they recognize sTn [49]. The most commonly used mAbs in breast cancer investigations are B72.3, TKH2 and HB-STn1. B72.3 appeared to be specific for clustered sTn but also cross-reacts with Tn clusters $[52,53]$. In contrast, TKH 2 reacts more strongly to monomeric sTn conjugated to keyhole limpet hemocyanin (STn-KLH) than B72.3 [54].

The reported occurrence of sTn expression in breast cancer is highly variable. It is commonly accepted that at least 25 to $30 \%$ of breast cancers are sTn-positive [51]. The reported ranges are 20 to $80 \%$ using B72.3 and 30 to $60 \%$ using HB-STn1 [49], and correlation with known prognosis markers varies from one study to another. Correlation with a decreased overall survival seems to be the more consistent correlation through the literature. Kinney and colleagues proposed that sTn was an independent predictor of poor prognosis of breast cancers [55]. Miles and colleagues, however, reported a significant correlation of sTn expression with the decreased survival in the restricted node-positive patient group [7], whereas Leivonen and colleagues limited the association to the short-term prognosis [56].

Induction of sTn expression by transfection of the breast cancer cell line with ST6GalNAc I cDNA decreased the adhesion of cells to matrix proteins, and increased mobility and tumour growth in a xenograft model $[10,11,50]$. These observations are in accordance with a more aggressive phenotype of cancer cell that is usually associated with sTn expression but remain to be elucidated at the molecular level. Of the various sTn-positive proteins present in these transfected cell lines, only four have been identified: MUC1 and CD44 in human [10], and integrin $\beta_{1}$ [57] and osteopontin [58] in mouse. All of these molecules have described functions in adhesion and/or migration, and it has been suggested that the modification of their $O$ glycosylation may influence this function and the mobility of the cancer cells.

\section{Lewis antigens in breast cancer}

\section{Structure and biosynthesis of Lewis antigens}

The histoblood group Lewis antigens are found in most human epithelial tissues, where they are expressed at the terminal part of glycolipid and glycoprotein glycan chains [59]. These antigens derive from the substitution of type 1 (Galß1-3GlcNAc) or type 2 (Galß1-4GlcNAc) disaccharide sequences by fucose and sialic acid residues (Figure 3). Le $e^{\mathrm{a}} \mathrm{Le}^{\mathrm{b}}$ and sLe ${ }^{\mathrm{a}}$ derive from type 1 sequences, and $\mathrm{Le}^{\mathrm{x}}, \mathrm{Le}^{\mathrm{y}}$ and $\mathrm{sLe}^{\mathrm{x}}$ derive from type 2. In healthy individuals, type $1\left(\mathrm{Le}^{\mathrm{a}}\right.$ and $\left.\mathrm{Le}^{\mathrm{b}}\right)$ antigens are widely expressed, while type $2\left(\operatorname{Le}^{\mathrm{x}}\right.$ and $\left.\mathrm{Le}^{\mathrm{y}}\right)$ antigens are only expressed at relatively low levels. The biosynthesis of these antigens requires specific fucosyltransferases and sialyltransferases (Table 1).

The GlcNAc $\alpha 1,4$-fucosylation of type 1 disaccharide generates $\mathrm{Le}^{\mathrm{a}}$ antigen, whereas the $\alpha 1,3$-fucosylation of type 2 gives Le $\mathrm{e}^{\mathrm{x}}$ (Figure 3).The fucosyltransferases Fuc'T III, FucT IV, FucT VI and FucT IX catalyse the transfer of a fucose residue onto GlcNAc of type 1 or type 2 disaccharides, thus synthesizing $\alpha 1,3$-fucosylated and, in the case of FucT III, $\alpha 1,4$-fucosylated glycans [60-62]. FucT III is the only enzyme responsible for the synthesis of $\mathrm{Le}^{\mathrm{a}}$ and $\mathrm{sLe}^{\mathrm{a}}$ in vivo and is called the Lewis enzyme. The fucosyltransferases FucT I and FucT II are responsible for the Gal $\alpha 1,2$-fucosylation of $\mathrm{Le}^{\mathrm{a}}$ or $\mathrm{Le}^{\mathrm{x}}$, generating $\mathrm{Le}^{\mathrm{b}}$ or $\mathrm{Le}^{\mathrm{y}}$ antigens, respectively (Figure 3 ). FucT I (H enzyme) preferentially fucosylates type 1, whereas FucT II (Se enzyme) determines the expression

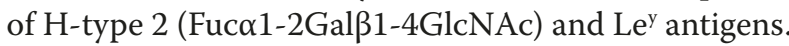

The biosynthesis of sialylated Lewis antigens (sLe ${ }^{a}$ and $\mathrm{sLe}^{\mathrm{x}}$ ) requires first the $\alpha 2,3$-sialylation of $\mathrm{Gal}$ prior to $\alpha 1,3 / 4$-fucosylation. ST3Gal III [63], preferentially acting on type 1 rather than on type 2 disaccharides, is involved in sLe ${ }^{a}$ synthesis. ST3Gal IV and ST3Gal VI mainly act on type 2 disaccharide, leading to the biosynthesis of $\mathrm{sLe}^{\mathrm{x}}$ [64], but both also share acceptor specificity with ST3Gal III. For the subsequent fucosylation, FucT III is the main enzyme involved in the biosynthesis of sLe ${ }^{a}$ [65], whereas FucT VII $[62,66]$ shows a restricted substrate specificity since it can form only sLe ${ }^{x}[67]$.

\section{Overexpression of Lewis antigens in breast cancer}

The expression of sialyl-Lewis antigens is usually altered in breast cancer. Normal breast commonly expresses Le $\mathrm{e}^{\mathrm{x}}$, mainly in the apical part of cell ducts, together with MUC1. sLe $\mathrm{s}^{\mathrm{x}}$ and $\mathrm{sLe}^{\mathrm{y}}$ epitopes may also be sometimes detected in normal breast, but with a low intensity [16]. On the contrary, sLe ${ }^{\mathrm{a}}$ and $\mathrm{sLe}^{\mathrm{x}}$ expression is found to be increased in breast cancer tissues, including primary breast carcinoma lesions [68]. Furthermore, levels of expression of sLe ${ }^{\mathrm{x}}$ are higher in patients who had distant metastasis compared with patients presenting nonmetastatic cancers [69]. The expression of sialyl-Lewis 


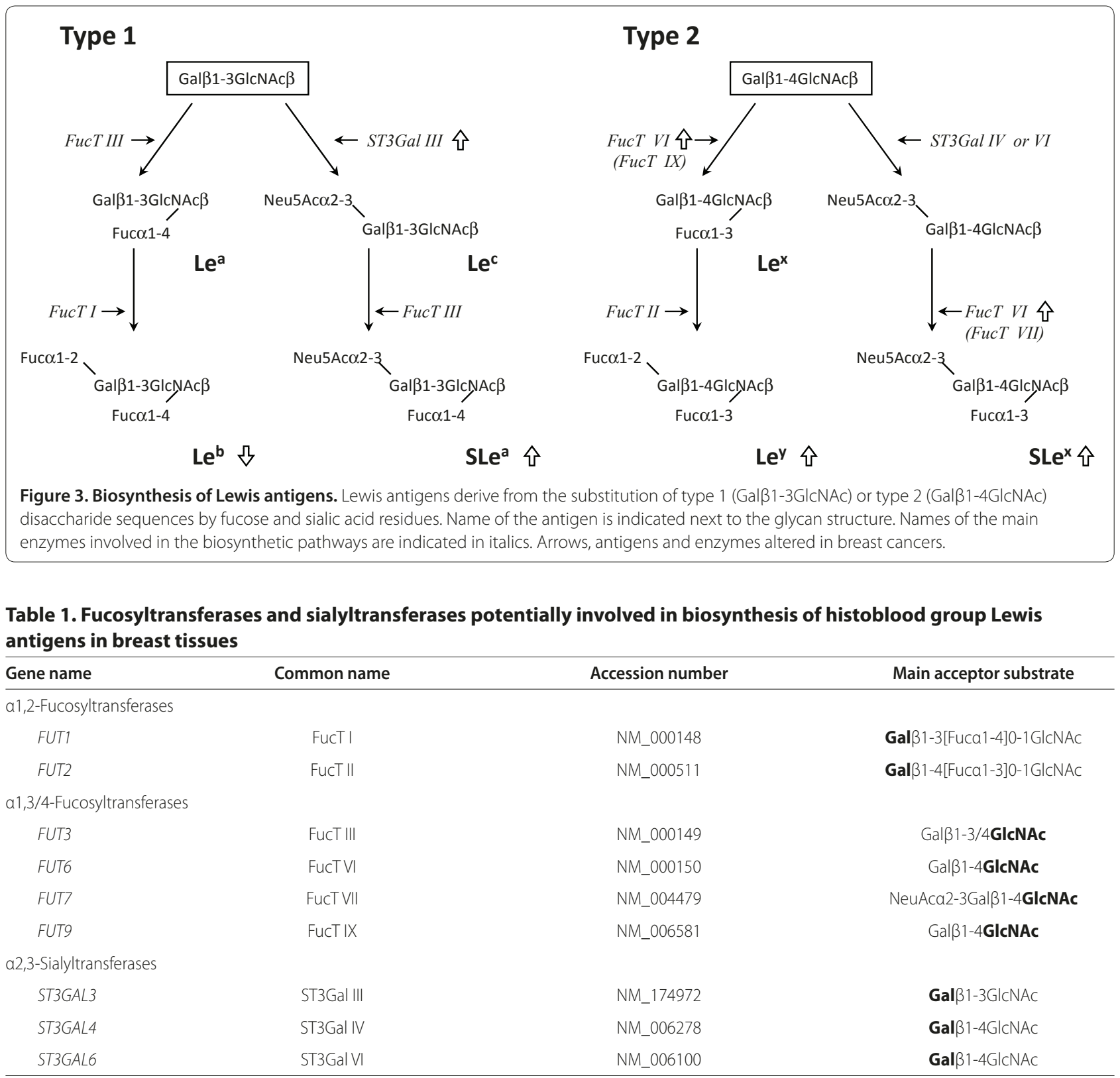

The acceptor monosaccharide is indicated in bold.

antigens is weak in carcinoma in situ, is moderate in invasive carcinomas without metastases and is high in primary carcinoma with lymph node metastases, showing a good correlation with the metastatic risk in breast cancer patients [70]. Immunohistochemistry of breast cancer tissue suggests that $\mathrm{sLe}^{\mathrm{x}}$ expression is an independent prognostic indicator of survival regardless of the size of the primary tumour and lymph node involvement [71].

RNA analysis of tumours indicated that FucT VI expression correlates with the levels of sLe $\mathrm{e}^{\mathrm{x}}$. Furthermore, transfection of the FUT6 gene into MCF-7 breast cancer cells showed that FucT VI is responsible for an enhancement of sLe $\mathrm{e}^{\mathrm{x}}$ expression [72]. The downregulation of ST3Gal IV increased MCF-7 cell adhesion and decreased MDA-MB-231 cell migration, suggesting that $\alpha 2,3$-sialylation played a crucial role in the adhesion and tumour metastases [73]. In parallel, the level of ST3Gal III expression is associated with axillary lymph node involvement and a reduced overall survival of patients $[8,9]$.

A general reduced expression of type 1 carbohydrate antigens and increased expression of type 2 antigens in breast cancer tissues has also been reported $[4,6]$, and the relative expression of type 2 carbohydrate antigens seems capable of serving as a prognostic factor. As much as $80 \%$ 
of breast tumours have lost the expression of Le ${ }^{\mathrm{b}}$ antigen, which correlates with the degree of malignancy and invasiveness [74].

The expression level of $\mathrm{sLe}^{\mathrm{x}}$ is also increased in the serum of patients with advanced breast cancer $[69,75]$ and is therefore a good candidate as a diagnosis marker. In combination with serum CA15-3, the most commonly used breast cancer marker, the measurement of serum sLe ${ }^{\mathrm{x}}$ improves monitoring - for $78.5 \%$ of detected metastatic breast cancer, compared with $61.5 \%$ when CA15-3 is used alone [76].

The $\mathrm{Le}^{\mathrm{y}}$ antigen is also overexpressed in 60 to $90 \%$ of cancer of epithelial origin, including breast cancer [77]. A clinical study showed that high expression of $\mathrm{Le}^{\mathrm{y}}$ correlated with high grade and poor prognosis, and significantly decreased patient survival in lymph node-negative breast carcinoma [78]. Showing restricted expression on epithelial surfaces in normal tissues, Le ${ }^{\mathrm{y}}$ also constitutes a good candidate for cancer immunotherapy [79].

\section{Implication of sialyl-Lewis antigens in metastasis}

The expression of $\mathrm{SLe}^{\mathrm{x}}$ on leukocytes contributes to their function in the inflammatory response via interaction with E-selectin expressed on endothelial cells. By exposing $\mathrm{sLe}^{\mathrm{x}}$ at the cell surface, malignant cells can use a similar strategy for the extravasation from the blood circulation and metastasis, targeting tissues where Eselectin is highly expressed.

Both P-selectin and E-selectin expression is significantly enhanced on endothelial cells of breast cancer patients [68], consistent with the proposal that $\mathrm{sLe}^{\mathrm{x}}$ binding to selectins aids cancer cell metastasis. A high tumour-associated ST3Gal III expression and a high Eselectin serum concentration were associated with a bad prognosis for relapse-free survival and overall survival in patients with node-negative breast cancer [8]. In both canine mammary carcinoma and the human inflammatory breast cancer model, the cellular expression of Ecadherin and $\mathrm{sLe}^{\mathrm{x}}$ are inversely correlated, suggesting a biologically coordinated mechanism of E-cadherin and sLe $^{\mathrm{x}}$ expression essential for tumour establishment and metastatic progression [80].

\section{Gangliosides in breast cancer}

\section{Structure and biosynthesis of gangliosides}

Gangliosides are expressed at the plasma membrane of cells, especially in developing tissues and the adult central nervous system. Gangliosides structurally and biosynthetically derive from lactosylceramide (LacCer), and additional sugar residues - including sialic acid, $N$-acetylgalactosamine and galactose - are transferred in a stepwise manner by a series of specific GTs [81] (Figure 4). $G_{M 3}, G_{D 3}$ and $G_{T 3}$ are the starting points for the biosynthesis of a-series, b-series and c-series gangliosides, respectively (Figure 4). The relative amounts of these glycosphingolipids determine the amount of complex gangliosides of each series. The amount of complex gangliosides is therefore dependent on the level of expression and activity of several GTs, including $G_{M 3}$ synthase (ST3Gal V), $\mathrm{G}_{\mathrm{D} 3}$ synthase (ST8Sia I), $\mathrm{G}_{\mathrm{T} 3}$ synthase (ST8Sia $\mathrm{V})$ and $\mathrm{G}_{\mathrm{M} 2 / \mathrm{D} 2}$ synthase ( $\beta 1,4-$ GalNAc T1) (Table 2).

\section{Overexpression or neo-expression of gangliosides in breast cancer}

The neo-expression of gangliosides has been usually demonstrated in a variety of cancers - especially in neuroectoderm-derivated tumours, in which they play a key role in invasion and metastasis. Breast tumour tissues were shown to be distinct from normal mammary tissues in terms of ganglioside composition. The gangliosides $\mathrm{G}_{\mathrm{M} 3}, \mathrm{G}_{\mathrm{D} 3}$ and the derivatives 9-O-acetyl- $\mathrm{G}_{\mathrm{D} 3}$ (CDw60 antigen) and 9-O-acetyl- $\mathrm{G}_{\mathrm{T} 3}$, which show a very restricted expression in normal breast tissues, are overexpressed in about $50 \%$ of IDC [82].

The $N$-glycolyl- $\mathrm{G}_{\mathrm{M} 3}$ is also detected in IDC, with $100 \%$ efficiency in primary tumours for women diagnosed with stage II breast cancer [82,83]. Neu5Gc is normally absent in human due to the irreversible inactivation of the CMAH gene encoding the CMP-Neu5Ac hydroxylase. The lack of the enzyme responsible for the conversion of CMP-Neu5Ac in CMP-Neu5Gc results in the total absence of Neu5Gc in healthy human tissues. On the contrary, Neu5Gc was shown to be expressed on glycoproteins and gangliosides in melanoma, colon, retinoblastoma and breast cancers.

The expression of GTs implicated in ganglioside biosynthesis can be also altered in breast cancer tumours. Two clinical studies have shown that the $G_{D 3}$ synthase (ST8Sia I) displayed higher expression among oestrogen receptor-negative breast cancer tumours [84]. ST8SIA1 overexpression was associated with poor pathohistological grading in oestrogen receptor-negative tumours and lower survival of patients [85]. In contrast, a better prognosis for oestrogen receptor-positive samples with high expression of ST8SIA1 was noticed [85].

It has been shown that silencing of $\mathrm{G}_{\mathrm{M} 3}$ synthase in mammary murine 4T1 cells significantly inhibited cell migration, invasion and anchorage-independent growth in vitro, as well as lung metastasis in vivo. In parallel, overexpression of $\mathrm{G}_{\mathrm{M} 3}$ synthase in nonmetastatic 67NR cells significantly restores the malignant phenotype [86]. We have recently demonstrated that overexpression of $G_{D 3}$ synthase in MDA-MB-231 cells is associated with increased proliferation, especially in the absence of serum or exogenous growth factors [13]. $G_{D 3}$ synthaseoverexpressing cells bypass the need of serum for cell growth by the activation of Erk/MAPK, PI3K/Akt and SAPK/JNK pathways (unpublished results). These data 


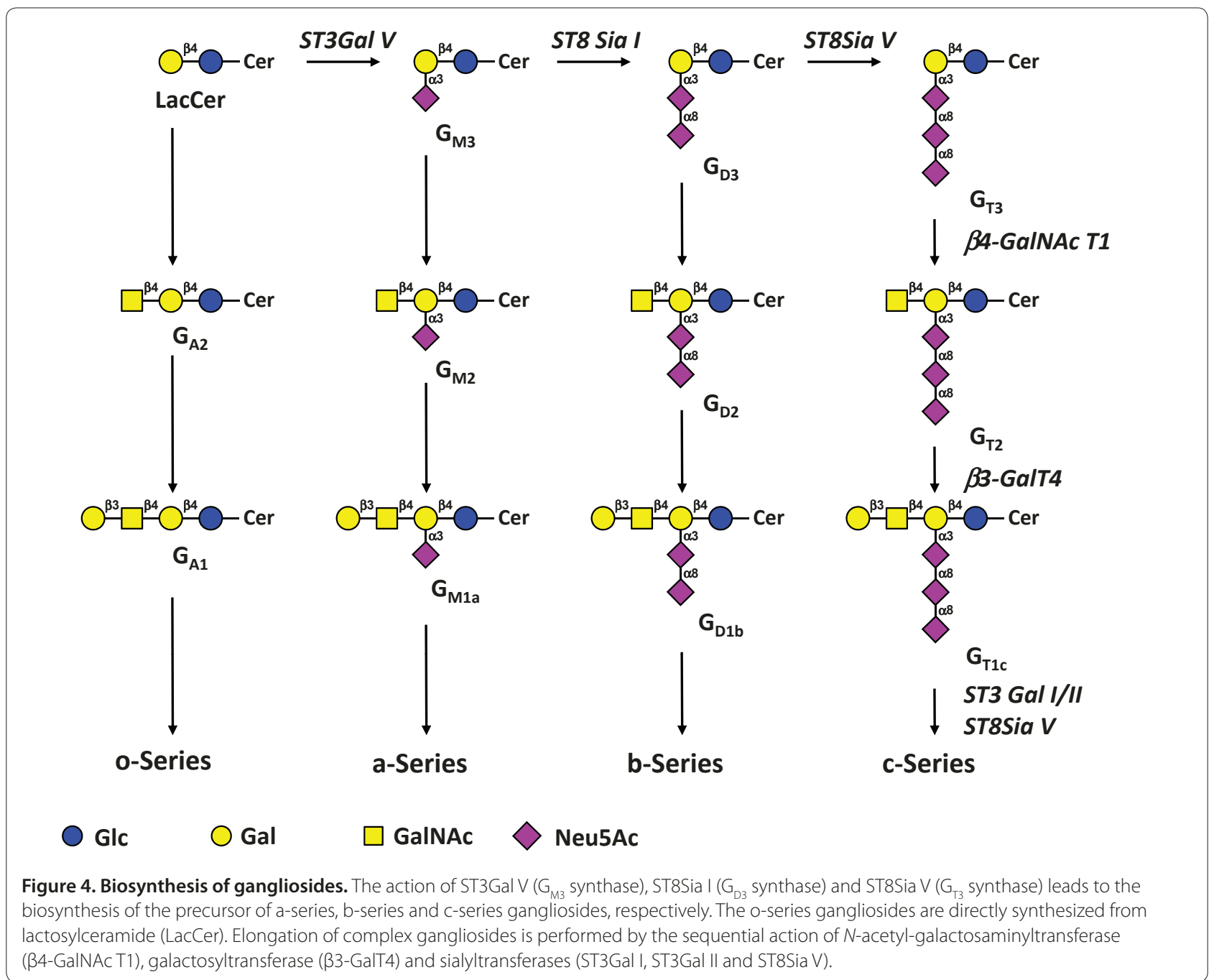

suggest that $G_{M 3}$ or $G_{D 3}$ synthase overexpression may contribute to increasing the malignant properties of breast cancer cells by mediating cell proliferation and migration. Recently, the role of ST6GalNAc V, a sialyltransferase involved in the biosynthesis of $\alpha$-series gangliosides, in breast cancer metastasis to the brain has been clearly demonstrated. Normally restricted to the brain, the expression of ST6GalNAc V enhances the adhesion of breast cancer cells to brain endothelium and their passage through the blood-brain barrier, highlighting the role of cell surface glycosylation in organspecific metastatic interactions [12].

\section{Future perspectives for therapy}

From the data summarized above, it appears that a limited number of TACAs are expressed in breast cancer and associated with restricted histopathological markers such as the oestrogen receptor status of tumours (Table 3). Breast cancer cells express truncated Core1-based
$O$-glycans, including $\mathrm{T}, \mathrm{Tn}$ and $\mathrm{sTn}$ antigens. The expression of sialyl-Lewis antigens is also altered in breast carcinoma with a good correlation with metastatic risk, and complex gangliosides are overexpressed in IDC.

Although some TACAs have been shown as strong markers of a poor prognosis (for example, sLe ${ }^{\mathrm{x}}$ or sTn), they have not yet reached the clinic. Indeed, the strongest marker of prognosis in breast cancer remains the invasion of the lymph nodes determined during surgery. Unless another marker proves to be of superior quality or independent of lymph node involvement, it is very unlikely to be useful for clinic application. As TACAs are more or less associated with lymph node invasion and/or restricted to specific groups of patients, their use as prognosis markers appears rather limited. However, since TACAs seem to be functionally involved in cancer progression, one of their most promising uses in the future remains being targets for treatments designed for specific groups of patients. 
Table 2. Main glycosyltransferases involved in biosynthesis of gangliosides

\begin{tabular}{|c|c|c|c|}
\hline Gene name & Common name & Accession number & Main acceptor substrate \\
\hline \multicolumn{4}{|l|}{ Glucosyltransferase } \\
\hline UGCG & GlcCer synthase & NM 003358.1 & Ceramide (Cer) \\
\hline \multicolumn{4}{|c|}{ Galactosyltransferases } \\
\hline B4GALT6 & LacCer synthase & NM_004775 & Glca1-Cer \\
\hline B3GALT4 & B3-GalT4 & NM_003782.3 & GalNAc $\beta 1-4[$ NeuAc0-3]Galß1-4Glca1-Cer \\
\hline \multicolumn{4}{|c|}{ N-Acetyl-galactosaminyltransferase } \\
\hline B4GALNACT1 & $\mathrm{G}_{\mathrm{M}^{\prime}{ }^{\prime}} \mathrm{G}_{\mathrm{D} 2^{\prime}} \mathrm{G}_{\mathrm{T} 2}$ synthase & NM_001478.2 & [NeuAc0-3]Gal $\beta 1-4 G l c a 1-C e r$ \\
\hline \multicolumn{4}{|l|}{ Sialyltransferases } \\
\hline ST3GALI & ST3Gal I & NM_003033.3 & Gal $\beta 1-3 G a l N A c \beta 1-4[$ NeuAc0-3] Gal $\beta 1-4 G l c a 1-C e r$ \\
\hline ST3GAL2 & ST3Gal II & NM_006927.3 & Gal $\beta 1$-3GalNAc $\beta 1-4[$ NeuAc0-3] Gal $\beta 1-4 G l c a 1-C e r$ \\
\hline ST3GAL5 & ST3GalV & NM_003896.3 & Galß1-4Glca1-Cer \\
\hline ST6GALNAC5 & ST6GalNAcV & NM_030965.1 & NeuAca2-3Galß1-3GaINAc $\beta 1$-4Gal $\beta 1$-4Glca1-Cer \\
\hline ST8SIAT & ST8Sia l & NM_003034.3 & NeuAca2-3Galß1-4Glca1-Cer \\
\hline ST8Sia5 & ST8Sia V & NM_013305.4 & NeuAca2-8NeuAca2-3Galß1-4Glca1-Cer \\
\hline
\end{tabular}

The acceptor monosaccharide is indicated in bold.

Table 3. Main tumour-associated carbohydrate antigens expressed in breast carcinomas

\begin{tabular}{|c|c|c|c|c|}
\hline TACA & DCIS & IDC & Altered pathway & Comments \\
\hline \multicolumn{5}{|l|}{ Mucin-type antigens } \\
\hline Thomsen-nouvelle & High & High & $\begin{array}{l}\text { COSMC mutation, decrease in C1 } \beta 3 \text { GalT } \\
\text { activity }\end{array}$ & $\begin{array}{l}\text { Expressed in almost } 90 \% \text { of breast } \\
\text { cancers }\end{array}$ \\
\hline Thomsen-Friedenreich & ND & High & $\begin{array}{l}\text { Decrease in Core2 } \beta 6 \text {-GlcNAc-T expression, } \\
\text { decrease in Core1 sialylation }\end{array}$ & \\
\hline Sialyl-Thomsen-nouvelle & ND & High & $\begin{array}{l}\text { Increase in ST6GaINAC I expression, decrease } \\
\text { in Core } 2 \beta 6 \text {-GICNAc-T expression, alteration } \\
\text { of COSMC function }\end{array}$ & $\begin{array}{l}25 \text { to } 30 \% \text { of breast cancers, correlated } \\
\text { with a decreased survival in } \\
\text { node-positive patients }\end{array}$ \\
\hline \multicolumn{5}{|l|}{ Lewis antigens } \\
\hline Sialyl-Lewis ${ }^{x}$ & Weak & High & $\begin{array}{l}\text { Increased expression of FucT (FucT VI and } \\
\text { FucT VII) }\end{array}$ & $\begin{array}{l}\text { Higher in metastatic compared with } \\
\text { nonmetastatic cancers }\end{array}$ \\
\hline Sialyl-Lewis ${ }^{a}$ & Weak & High & Increased expression of FucT (FucT III) & \\
\hline Lewisy & Low & High & Increased expression of FucT & $\begin{array}{l}\text { Overexpressed in } 60 \text { to } 90 \% \text { of breast } \\
\text { cancer }\end{array}$ \\
\hline \multicolumn{5}{|l|}{ Gangliosides } \\
\hline$G_{M 3}$ & ND & Increased & Increased expression of ST3GalV & 2.8-fold compared with normal tissue \\
\hline $\mathrm{G}_{\mathrm{D} 3}$ & ND & Increased & Increased expression of ST8Sia I & 1.7-fold compared with normal tissue \\
\hline 9-O-acetyl-G ${ }_{D 3}$ & ND & Neo-expression & Increase of sialic acid acetylation & \\
\hline 9-O-acetyl- $\mathrm{G}_{\mathrm{T}}$ & ND & Neo-expression & Increase of sialic acid acetylation & \\
\hline$N$-glycolyl-G ${ }_{M 3}$ & ND & 65 to $70 \%$ & Unknown & $100 \%$ in stage II primary tumours \\
\hline
\end{tabular}

DCIS, ductal carcinoma in situ; IDC, invasive ductal carcinoma; ND, not determined; TACA, tumour-associated carbohydrate antigen.

Different methods can take advantage of TACA expression to treat breast cancer, such as blocking their biosynthesis or biological function, or using them as molecular targets in immunotherapy. Blocking the biosynthesis of glycans using chemical inhibitors has been shown to change the phenotype of breast cancer cells in culture, making them less aggressive $[87,88]$. Such an approach, however, is difficult to adapt to human therapy because both healthy and diseased cells are using their glycans in a variety of functions. There are high risks that detrimental effects of a chemical inhibitor on healthy cells would counterbalance or avoid the beneficial effect of the molecule on cancer cells. In order to develop further, this field will have to await improvement in the 
drug-targeting or drug delivery systems, such as the booming nanotechnologies [89].

Alternatively, one may consider specifically altering the expression of GTs involved in TACA biosynthesis. Little is still known about the molecular mechanisms leading to aberrant expression of GTs in cancer. Gain or loss of GT expression could be attributed to loss of chromosomal integrity often observed in cancers, leading to duplication, deletion or transposition of chromosomal segments involving glycosyltransferase genes. As an example, elevated ST6Gal I expression in murine W16 cells has been shown to be the result of DNA rearrangement in the st6gal1 locus resulting from the transposition of a retroviral-like transposable element upstream of the st6gal1 ORF [90]. Changes of gene expression do not always reflect genomic rearrangements, however, as comparison of the Comparative Genomic Hybridization Array and the RNA microarray do not always show absolute correlation. Expression of GT genes is often regulated at the transcriptional level [91], and several examples have shown that GT genes, including ST6GAL1 [2] and MGAT5 [3], can be regulated by oncogenes. Only a limited number of promoters of GT genes have been characterized [91], and this field is in need of further data in order to understand which factors of transcription, signalling pathways and, eventually, membrane receptors are involved in this cancer-specific deregulation. The knowledge of the intracellular molecular mechanisms regulating the expression of GTs might open new options to specifically impair TACA expression in cancer cells.

Functions of TACAs often involve interaction with glycan-specific receptors, such as selectins with sialylLewis antigens. Attempts can be made to block this interaction, by masking either the glycans or its receptor. Several studies have shown that masking $\mathrm{T}$ antigens with specific peptides [92] or mAbs [93] can inhibit interaction of breast cancer cells with the endothelium and protect from metastasis. One advantage of this approach is that the lectin(s) recognizing the TACA does not need to be identified to block the interaction. Some limitations remain, however, such as the risk to induce unwanted physiological responses triggered by the same type of interactions (or loss of interaction), or the clinical viability of these compounds in terms of toxicity, body clearance or administration.

Active immunotherapy has been thoroughly investigated during the past 40 years as an alternative approach for cancer treatment. As glycans are naturally highly immunogenic, they have been extensively used for the design of immunotherapy strategies against breast cancer.

As early as in 1977, Springer and collaborators attempted to immunize patients with desialylated autologous red blood cells, in order to trigger a response to $\mathrm{T}$ antigen. He reported a significantly improved 5-year survival (100\%) and 10-year survival (44\%) compared with the nonimmunized population [38]. Although of small scale and somewhat unorthodox, this study paved the way for further development of anti-TACA vaccines.

Ganglioside-based anti-idiotype vaccines focusing on $N$-glycolyl- $\mathrm{G}_{\mathrm{M} 3}$ have been developed for specific active immunotherapy against breast cancer [94]. The 1E10 $\mathrm{mAb}$ (Racotumomab) is an anti-idiotype vaccine to P3 $\mathrm{mAb}$, which recognized Neu5Gc-G $\mathrm{G}_{\mathrm{M} 3}$. Vaccination with $1 \mathrm{E} 10$ of $\mathrm{BALB} / \mathrm{c}$ mice challenged with the murine F3II mammary carcinoma leads to breast tumour growth suppression and a decrease of lung metastasis [95]. Moreover, the anti-tumour effect of 1E10 is enhanced by combination with a low-dose of cyclophosphamide [96]. Results of phase I clinical trials have shown that 1E10 vaccine was relatively well tolerated and able to produce a specific response against Neu5Gc-containing gangliosides in high-risk (stage III) or metastatic breast cancer [97,98].

Clustered sTn haptens conjugated to keyhole limpet hemocyanin (Theratope ${ }^{\mathrm{Tx}}$; Biomira, Edmonton, AB, Canada) have also been used to immunize breast cancer patients [99]. Although the results of the first phase III clinical trial failed to show significant benefit, it has to be mentioned that patients were never screened for expression of sTn antigen in the tumours. The lack of significant benefit for the total population could therefore be explained by the low representation of patients presenting sTn-positive tumours (25 to 30\%). Recently, we clearly demonstrated that Theratope ${ }^{\mathrm{TM}}$ induced tumour protection in a relevant murine model. The protection was dependent on both the presence of the sTn antigen in the tumour and the anti-sTn antibodies raised by immunization. Interestingly anti-sTn antibodies were able to recognize a wide range of sTn-positive proteins expressed by mammary carcinomas, suggesting that multi-targeting of the response was important to induce tumour protection [58].

Despite decades of research and evident proofs of concept in favour of anti-TACA cancer vaccines, one has to acknowledge that none of them have reached the clinic. One possible method of improvement is a better definition of patients who are most susceptible to benefit from the designed treatment. As TACAs are expressed in distinguishable groups of patients based on immunohistology or gene profiling expression, one may therefore consider personalizing the treatment according to expression of putative targets. Another way is to design multi-epitope targeting vaccines to cover a variety of targets found in different patient populations and to possibly trigger multi-antigenic response in each of the patients. Glycopeptide dendrimers have been developed to present simultaneously up to six different antigens (Tn, T, Globo H, G ${ }_{\mathrm{M} 2}, \mathrm{Le}^{\mathrm{y}}$, and MUC1-Tn antigens) and 
have been assessed in immunization trials to compare multi-antigenic responses with mono-antigenic responses [100].

As the future of breast cancer treatment lies in a combination of patient-tailored and multi-targeting strategies, we believe that TACAs - because of their profile of expression and their proaggressive function will be considered potent molecular targets.

\section{Abbreviations}

C1ß3GalT, Core1 $\beta 1$,3-galactosyltransferase (EC 2.4.1.122); GT, glycosyltransferase; HPA, Helix pomiata agglutinin; IDC, invasive ductal carcinoma; Le, Lewis; mAb, monoclonal antibody; MGL, macrophage galactose-type lectin; ORF, open reading frame; PNA, Arachis hypogea agglutinin; sLe, sialyl-Lewis; sTn, sialyl-Thomsen-nouvelle; T, ThomsenFriedenreich; TACA, tumour-associated carbohydrate antigen; Tn, Thomsennouvelle; VA, Vicia villosa agglutinin isolectin $B_{4}$

\section{Competing interests}

The authors declare that they have no competing interests.

\section{Acknowledgements}

The present work was supported by the University of Sciences and Technologies of Lille, the Association pour la Recherche sur le Cancer (grant numbers 7936 and 5023), La Ligue régionale contre le Cancer and the PAI Hubert Curien France-Korea STAR.

\section{Author details}

'Structural and Functional Glycobiology Unit, UMR CNRS 8576, University of Sciences and Technologies of Lille, 59655 Villeneuve d'Ascq, France. ${ }^{2}$ Université Lille Nord de France, F-59000 Lille, France. ${ }^{3}$ Breast Cancer Biology Group, Research Oncology, King's College London, London SE1 9RT, UK.

Published: 8 June 2010

\section{References}

1. Varki A: Selectin ligands. Proc Natl Acad Sci USA 1994, 91:7390-7397.

2. Le Marer N, Laudet V, Svensson EC, Cazlaris H, Van Hille B, Lagrou C, Stehelin D, Montreuil J, Verbert A, Delannoy P: The C-Ha-ras oncogene induces increased expression of beta-galactoside alpha-2, 6-sialyltransferase in rat fibroblast (FR3T3) cells. Glycobiology 1992, 2:49-56.

3. Buckhaults P, Chen L, Fregien N, Pierce M: Transcriptional regulation of $\mathrm{N}$-acetylglucosaminyltransferase V by the src oncogene. J Biol Chem 1997, 272:19575-19581.

4. Narita T, Funahashi H, Satoh Y, Watanabe T, Sakamoto J, Takagi H: Association of expression of blood group-related carbohydrate antigens with prognosis in breast cancer. Cancer 1993, 71:3044-3053.

5. Soares R, Marinho A, Schmitt F: Expression of sialyl-Tn in breast cancer. Correlation with prognostic parameters. Pathol Res Pract 1996, 192:1181-1186

6. Ura Y, Dion AS, Williams CI, Olsen BD, Redfield ES, Ishida M, Herlyn M, Major PP: Quantitative dot blot analyses of blood-group-related antigens in paired normal and malignant human breast tissues. Int J Cancer 1992, 50:57-63.

7. Miles DW, Happerfield LC, Smith P, Gillibrand R, Bobrow LG, Gregory WM, Rubens RD: Expression of sialyl-Tn predicts the effect of adjuvant chemotherapy in node-positive breast cancer. Br J Cancer 1994, 70:1272-1275

8. Hebbar M, Krzewinski-Recchi MA, Hornez L, Verdiere A, Harduin-Lepers A Bonneterre J, Delannoy P, Peyrat JP: Prognostic value of tumoral sialyltransferase expression and circulating E-selectin concentrations in node-negative breast cancer patients. Int J Biol Markers 2003, 18:1 16-122.

9. Recchi MA, Hebbar M, Hornez L, Harduin-Lepers A, Peyrat JP, Delannoy P: Multiplex reverse transcription polymerase chain reaction assessment of sialyltransferase expression in human breast cancer. Cancer Res 1998 58:4066-4070

10. Julien S, Adriaenssens E, Ottenberg K, Furlan A, Courtand G, VercoutterEdouart AS, Hanisch FG, Delannoy P, Le Bourhis X: ST6GalNAc I expression in MDA-MB-231 breast cancer cells greatly modifies their O-glycosylation pattern and enhances their tumourigenicity. Glycobiology 2006, 16:54-64

11. Julien S, Lagadec C, Krzewinski-Recchi MA, Courtand G, Le Bourhis X, Delannoy P: Stable expression of sialyl-Tn antigen in T47-D cells induces a decrease of cell adhesion and an increase of cell migration. Breast Cancer Res Treat 2005, 90:77-84.

12. Bos PD, Zhang XH, Nadal C, Shu W, Gomis RR, Nguyen DX, Minn AJ, van de Vijver MJ, Gerald WL, Foekens JA, Massagué J: Genes that mediate breast cancer metastasis to the brain. Nature 2009, 459:1005-1009.

13. Cazet A, Groux-Degroote S, Teylaert B, Kwon KM, Lehoux S, Slomianny C, Kim $\mathrm{CH}$, Le Bourhis X, Delannoy P: GD3 synthase overexpression enhances proliferation and migration of MDA-MB-231 breast cancer cells. Biol Chem 2009, 390:601-609.

14. Rakha EA, Boyce RW, Abd El-Rehim D, Kurien T, Green AR, Paish EC, Robertson JF, Ellis IO: Expression of mucins (MUC1, MUC2, MUC3, MUC4, MUC5AC and MUC6) and their prognostic significance in human breast cancer. Mod Pathol 2005, 18:1295-1304.

15. Hanisch FG, Uhlenbruck G, Peter-Katalinic J, Egge H, Dabrowski J, Dabrowski U: Structures of neutral O-linked polylactosaminoglycans on human skim milk mucins. A novel type of linearly extended poly- $\mathrm{N}$-acetyllactosamine backbones with Gal beta(1-4)GlcNAc beta(1-6) repeating units. J Bio/ Chem 1989, 264:872-883

16. Croce MV, Isla-Larrain M, Rabassa ME, Demichelis S, Colussi AG, Crespo M, Lacunza E, Segal-Eiras A: Lewis $\mathrm{x}$ is highly expressed in normal tissues: a comparative immunohistochemical study and literature revision. Pathol Oncol Res 2007, 13:130-138.

17. Muller S, Hanisch FG: Recombinant MUC1 probe authentically reflects cell-specific O-glycosylation profiles of endogenous breast cancer mucin. High density and prevalent core 2-based glycosylation. J Biol Chem 2002, 277:26103-26112.

18. Abecassis J, Collard R, Eber M, Pusel J, Fricker JP, Methlin G: Proteinases and sialyltransferase in human breast tumors. Int J Cancer 1984, 33:821-824.

19. Springer GF: T and Tn, general carcinoma autoantigens. Science 1984 224:1198-1206.

20. Springer GF, Desai PR, Murthy MS, Scanlon EF: Human carcinoma-associated precursor antigens of the NM blood group system. J Surg Oncol 1979, 11:95-106.

21. Schmitt FC, Figueiredo P, Lacerda M: Simple mucin-type carbohydrate antigens ( $\mathrm{T}$, sialosyl-T, $\mathrm{Tn}$ and sialosyl-Tn) in breast carcinogenesis. Virchows Arch 1995, 427:251-258

22. Tachibana K, Nakamura S, Wang H, Iwasaki H, Maebara K, Cheng L, Hirabayashi J, Narimatsu H: Elucidation of binding specificity of Jacalin toward O-glycosylated peptides: quantitative analysis by frontal affinity chromatography. Glycobiology 2006, 16:46-53.

23. Wu AM, Wu JH, Yang Z, Singh T, Goldstein IJ, Sharon N: Differential contributions of recognition factors of two plant lectins, Amaranthus caudatus lectin and Arachis hypogea agglutinin, reacting with ThomsenFriedenreich disaccharide (Galß1-3GaINAca1-Ser/Thr). Biochimie 2008 90:1769-1780

24. Lotan R, Skutelsky E, Danon D, Sharon N: The purification, composition, and specificity of the anti-T lectin from peanut (Arachis hypogaea). J Biol Chem 1975, 250:8518-8523.

25. Pereira ME, Kabat EA, Lotan R, Sharon N: Immunochemical studies on the specificity of the peanut (Arachis hypogaea) agglutinin. Carbohydr Res 1976, 51:107-118.

26. Hanisch FG, Baldus SE: The Thomsen-Friedenreich (TF) antigen: a critical review on the structural, biosynthetic and histochemical aspects of a pancarcinoma-associated antigen. Histol Histopathol 1997, 12:263-281.

27. Cao Y, Stosiek P, Springer GF, Karsten U: Thomsen-Friedenreich-related carbohydrate antigens in normal adult human tissues: a systematic and comparative study. Histochem Cell Biol 1996, 106:197-207.

28. Schindlbeck C, Jeschke U, Schulze S, Karsten U, Janni W, Rack B, Krajewski S, Sommer H, Friese K: Prognostic impact of Thomsen-Friedenreich tumor antigen and disseminated tumor cells in the bone marrow of breast cancer patients. Breast Cancer Res Treat 2007, 101:17-25.

29. Schindlbeck C, Jeschke U, Schulze S, Karsten U, Janni W, Rack B, Sommer H, Friese $\mathrm{K}$ : Characterisation of disseminated tumor cells in the bone marrow of breast cancer patients by the Thomsen-Friedenreich tumor antigen. Histochem Cell Biol 2005, 123:631-637.

30. Glinsky VV, Glinsky GV, Glinskii OV, Huxley VH, Turk JR, Mossine W, Deutscher SL, Pienta KJ, Quinn TP: Intravascular metastatic cancer cell homotypic aggregation at the sites of primary attachment to the endothelium. 
Cancer Res 2003, 63:3805-3811.

31. Yu LG, Andrews N, Zhao Q, McKean D, Williams JF, Connor LJ, Gerasimenko OV, Hilkens J, Hirabayashi J, Kasai K, Rhodes JM: Galectin-3 interaction with Thomsen-Friedenreich disaccharide on cancer-associated MUC1 causes increased cancer cell endothelial adhesion. J Biol Chem 2007, 282:773-781.

32. Berger EG: Tn-syndrome. Biochim Biophys Acta 1999, 1455:255-268.

33. Ju T, Cummings RD: Protein glycosylation: chaperone mutation in Tn syndrome. Nature 2005, 437:1252.

34. Ju T, Lanneau GS, Gautam T, Wang Y, Xia B, Stowell SR, Willard MT, Wang W, Xia JY, Zuna RE, Laszik Z, Benbrook DM, Hanigan MH, Cummings RD: Human tumor antigens $\mathrm{Tn}$ and sialyl Tn arise from mutations in Cosmc. Cancer Res 2008, 68:1636-1646

35. Yoo NJ, Kim MS, Lee SH: Absence of COSMC gene mutations in breast and colorectal carcinomas. Apmis 2008, 116:154-155.

36. Piller V, Piller F, Cartron JP: Comparison of the carbohydrate-binding specificities of seven $\mathrm{N}$-acetyl-D-galactosamine-recognizing lectins. Eur J Biochem 1990, 191:461-466.

37. Brooks SA: The involvement of Helix pomatia lectin (HPA) binding $\mathrm{N}$-acetylgalactosamine glycans in cancer progression. Histol Histopathol 2000, 15:143-158.

38. Springer GF: Immunoreactive T and Tn epitopes in cancer diagnosis, prognosis, and immunotherapy. J Mol Med 1997, 75:594-602.

39. Wang BL, Springer GF, Carlstedt SC: Quantitative computerized image analysis of $\mathrm{Tn}$ and $\mathrm{T}$ (Thomsen-Friedenreich) epitopes in prognostication of human breast carcinoma. J Histochem Cytochem 1997, 45:1393-1400.

40. Korourian S, Siegel E, Kieber-Emmons T, Monzavi-Karbassi B: Expression analysis of carbohydrate antigens in ductal carcinoma in situ of the breast by lectin histochemistry. BMC Cancer 2008, 8:136.

41. Konska G, Guerry M, Caldefie-Chezet F, De Latour M, Guillot J: Study of the expression of Tn antigen in different types of human breast cancer cells using VVA-B4 lectin. Oncol Rep 2006, 15:305-310.

42. Kawaguchi T, Takazawa H, Imai S, Morimoto J, Watanabe T, Kanno M, Igarash S: Expression of Vicia villosa agglutinin (VVA)-binding glycoprotein in primary breast cancer cells in relation to lymphatic metastasis: is atypical MUC1 bearing Tn antigen a receptor of VVA? Breast Cancer Res Treat 2006, 98:31-43.

43. Brooks SA, Leathem AJ: Prediction of lymph node involvement in breast cancer by detection of altered glycosylation in the primary tumour. Lancet 1991, 338:71-74

44. Leathem AJ, Brooks SA: Predictive value of lectin binding on breast-cancer recurrence and survival. Lancet 1987, 1:1054-1056

45. Danussi C, Coslovi A, Campa C, Mucignat MT, Spessotto P, Uggeri F, Paoletti S, Colombatti A: A newly generated functional antibody identifies $T n$ antigen as a novel determinant in the cancer cell-lymphatic endothelium interaction. Glycobiology 2009, 19:1056-1067

46. van Vliet SJ, Saeland E, van Kooyk Y: Sweet preferences of MGL: carbohydrate specificity and function. Trends Immuno/ 2008, 29:83-90.

47. Saeland E, van Vliet SJ, Backstrom M, van den Berg VC, Geijtenbeek TB, Meijer GA, van Kooyk Y: The C-type lectin MGL expressed by dendritic cells detects glycan changes on MUC1 in colon carcinoma. Cancer Immunol Immunother 2007, 56:1225-1236.

48. Napoletano C, Rughetti A, Agervig Tarp MP, Coleman J, Bennett EP, Picco G, Sale P, Denda-Nagai K, Irimura T, Mandel U, Clausen H, Frati L, TaylorPapadimitriou J, Burchell J, Nuti M: Tumor-associated Tn-MUC1 glycoform is internalized through the macrophage galactose-type C-type lectin and delivered to the HLA class I and II compartments in dendritic cells. Cancer Res 2007, 67:8358-8367.

49. Julien S, Delannoy P: Sialyl-Tn antigen in cancer: from diagnosis to therapy. In Recent Research Developments in Cancer. Volume 5. Edited by Pandalai SG. Kerala: Transworld Research Network; 2003:185-199.

50. Julien S, Krzewinski-Recchi MA, Harduin-Lepers A, Gouyer V, Huet G, Le Bourhis $X$, Delannoy P: Expression of sialyl-Tn antigen in breast cancer cells transfected with the human CMP-Neu5Ac: GalNAc alpha2,6sialyltransferase (ST6GalNac I) CDNA. Glycoconj J 2001, 18:883-893.

51. Sewell R, Backstrom M, Dalziel M, Gschmeissner S, Karlsson H, Noll T, Gatgens J, Clausen H, Hansson GC, Burchell J, Taylor-Papadimitriou J: The ST6GalNAc-I sialyltransferase localizes throughout the Golgi and is responsible for the synthesis of the tumor-associated sialyl-Tn O-glycan in human breast cancer. J Biol Chem 2006, 281:3586-3594.

52. Gold DV, Mattes MJ: Monoclonal antibody B72.3 reacts with a core region structure of O-linked carbohydrates. Tumour Biol 1988, 9:137-144.
53. Reddish MA, Jackson L, Koganty RR, Qiu D, Hong W, Longenecker BM: Specificities of anti-sialyl-Tn and anti-Tn monoclonal antibodies generated using novel clustered synthetic glycopeptide epitopes. Glycoconj J 1997, 14:549-560.

54. Ogata S, Koganty R, Reddish M, Longenecker BM, Chen A, Perez C, Itzkowitz $\mathrm{SH}$ : Different modes of sialyl-Tn expression during malignant transformation of human colonic mucosa. Glycoconj J 1998, 15:29-35.

55. Kinney AY, Sahin A, Vernon SW, Frankowski RF, Annegers JF, Hortobagyi GN, Buzdar AU, Frye DK, Dhingra K: The prognostic significance of sialyl-Tn antigen in women treated with breast carcinoma treated with adjuvant chemotherapy. Cancer 1997, 80:2240-2249.

56. Leivonen M, Nordling S, Lundin J, von Boguslawski K, Haglund C: STn and prognosis in breast cancer. Oncology 2001, 61:299-305.

57. Clement M, Rocher J, Loirand G, Le Pendu J: Expression of sialyl-Tn epitopes on beta1 integrin alters epithelial cell phenotype, proliferation and haptotaxis. J Cell Sci 2004, 117(Pt 21):5059-5069.

58. Julien S, Picco G, Sewell R, Vercoutter-Edouart AS, Tarp M, Miles D, Clausen H, Taylor-Papadimitriou J, Burchell JM: Sialyl-Tn vaccine induces antibodymediated tumour protection in a relevant murine model. Br J Cancer 2009, 100:1746-1754.

59. Ravn V, Dabelsteen E: Tissue distribution of histo-blood group antigens. Apmis 2000, 108:1-28.

60. Kaneko M, Kudo T, Iwasaki H, Ikehara Y, Nishihara S, Nakagawa S, Sasaki K, Shiina T, Inoko H, Saitou N, Narimatsu H: Alpha1,3-fucosyltransferase IX (Fuc-TIX) is very highly conserved between human and mouse; molecular cloning, characterization and tissue distribution of human Fuc-TIX. FEBS Lett 1999, 452:237-242.

61. Mollicone R, Gibaud A, Francois A, Ratcliffe M, Oriol R: Acceptor specificity and tissue distribution of three human alpha-3-fucosyltransferases. Eur J Biochem 1990, 191:169-176.

62. Natsuka S, Gersten KM, Zenita K, Kannagi R, Lowe JB: Molecular cloning of a CDNA encoding a novel human leukocyte alpha-1,3-fucosyltransferase capable of synthesizing the sialyl Lewis $x$ determinant. J Biol Chem 1994, 269:16789-16794.

63. Kitagawa H, Paulson JC: Cloning and expression of human Gal beta 1,3(4) GlcNAc alpha 2,3-sialyltransferase. Biochem Biophys Res Commun 1993, 194:375-382.

64. Ellies LG, Sperandio M, Underhill GH, Yousif J, Smith M, Priatel JJ, Kansas GS, Ley K, Marth JD: Sialyltransferase specificity in selectin ligand formation. Blood 2002, 100:3618-3625.

65. Kukowska-Latallo JF, Larsen RD, Nair RP, Lowe JB: A cloned human cDNA determines expression of a mouse stage-specific embryonic antigen and the Lewis blood group alpha(1,3/1,4)fucosyltransferase. Genes Dev 1990, 4:1288-1303.

66. Sasaki K, Kurata K, Kojima N, Kurosawa N, Ohta S, Hanai N, Tsuji S, Nishi T: Expression cloning of a GM3-specific alpha-2,8-sialyltransferase (GD3 synthase). J Biol Chem 1994, 269:15950-15956.

67. Maly P, Thall A, Petryniak B, Rogers CE, Smith PL, Marks RM, Kelly RJ, Gersten KM, Cheng G, Saunders TL, Camper SA, Camphausen RT, Sullivan FX, Isogai Y, Hindsgaul O, von Andrian UH, Lowe JB: The alpha(1,3)fucosyltransferase Fuc-TVII controls leukocyte trafficking through an essential role in L-, E-, and P-selectin ligand biosynthesis. Cell 1996, 86:643-653.

68. Renkonen J, Paavonen T, Renkonen R: Endothelial and epithelial expression of sialyl Lewis $(x)$ and sialyl Lewis(a) in lesions of breast carcinoma. Int J Cancer 1997, 74:296-300.

69. Matsuura N, Narita T, Mitsuoka C, Kimura N, Kannagi R, Imai T, Funahashi H, Takagi $\mathrm{H}$ : Increased level of circulating adhesion molecules in the sera of breast cancer patients with distant metastases. Jpn J Clin Oncol 1997, 27:135-139.

70. Jeschke U, Mylonas I, Shabani N, Kunert-Keil C, Schindlbeck C, Gerber B, Friese $\mathrm{K}$ : Expression of sialyl lewis $\mathrm{X}$, sialyl Lewis A, E-cadherin and cathepsin-D in human breast cancer: immunohistochemical analysis in mammary carcinoma in situ, invasive carcinomas and their lymph node metastasis. Anticancer Res 2005, 25:1615-1622.

71. Nakagoe T, Fukushima K, Itoyanagi N, Ikuta Y, Oka T, Nagayasu T, Ayabe H, Hara S, Ishikawa H, Minami H: Expression of ABH/Lewis-related antigens as prognostic factors in patients with breast cancer. J Cancer Res Clin Oncol 2002, 128:257-264.

72. Matsuura $\mathrm{N}$, Narita T, Hiraiwa N, Hiraiwa M, Murai H, Iwase T, Funahashi H, Imai T, Takagi H, Kannagi R: Gene expression of fucosyl- and sialyl-transferases which synthesize sialyl Lewisx, the carbohydrate ligands for E-selectin, in 
human breast cancer. Int J Oncol 1998, 12:1157-1164.

73. Hsu CC, Lin TW, Chang WW, Wu CY, Lo WH, Wang PH, Tsai YC: Soyasaponin-Imodified invasive behavior of cancer by changing cell surface sialic acids. Gynecol Oncol 2005, 96:415-422.

74. Idikio HA, Manickavel V: Lewis blood group antigens ( $a$ and $b$ ) in human breast tissues. Loss of Lewis-b in breast cancer cells and correlation with tumor grade. Cancer 1991, 68:1303-1308.

75. Abd Hamid UM, Royle L, Saldova R, Radcliffe CM, Harvey DJ, Storr SJ, Pardo M, Antrobus R, Chapman CJ, Zitzmann N, Robertson JF, Dwek RA, Rudd PM: A strategy to reveal potential glycan markers from serum glycoproteins associated with breast cancer progression. Glycobiology 2008, 18:1105-1118.

76. Kurebayashi J, Nomura T, Hirono M, Okubo S, Udagawa K, Shiiki S, Ikeda M, Nakashima K, Tanaka K, Sonoo H: Combined measurement of serum sialyl Lewis X with serum CA15-3 in breast cancer patients. Jpn J Clin Oncol 2006, 36:150-153.

77. Hellstrom I, Garrigues HJ, Garrigues U, Hellstrom KE: Highly tumor-reactive, internalizing, mouse monoclonal antibodies to Le(y)-related cell surface antigens. Cancer Res 1990, 50:2183-2190.

78. Madjd Z, Parsons T, Watson NF, Spendlove I, Ellis I, Durrant LG: High expression of Lewis $y / b$ antigens is associated with decreased survival in lymph node negative breast carcinomas. Breast Cancer Res 2005, 7:R780-R787.

79. Kelly MP, Lee FT, Smyth FE, Brechbiel MW, Scott AM: Enhanced efficacy of 90Y-radiolabeled anti-Lewis Y humanized monoclonal antibody hu3S193 and paclitaxel combined-modality radioimmunotherapy in a breast cancer model. J Nucl Med 2006, 47:716-725.

80. Pinho SS, Reis CA, Gartner F, Alpaugh ML: Molecular plasticity of E-cadherin and sialyl lewis $\mathrm{x}$ expression, in two comparative models of mammary tumorigenesis. PLoS One 2009, 4:e6636.

81. Tettamanti G: Ganglioside/glycosphingolipid turnover: new concepts. Glycoconj J 2004, 20:301-317.

82. Marquina G, Waki H, Fernandez LE, Kon K, Carr A, Valiente O, Perez R, Ando S: Gangliosides expressed in human breast cancer. Cancer Res 1996 56:5165-5171.

83. Oliva JP, Valdes Z, Casaco A, Pimentel G, Gonzalez J, Alvarez I, Osorio M, Velazco M, Figueroa M, Ortiz R, Escobar X, Orozco M, Cruz J, Franco S, Díaz M, Roque L, Carr A, Vázquez AM, Mateos C, Rubio MC, Pérez R, Fernández LE: Clinical evidences of GM3 (NeuGc) ganglioside expression in human breast cancer using the 14F7 monoclonal antibody labelled with (99m)Tc. Breast Cancer Res Treat 2006, 96:115-121.

84. Ruckhaberle E, Rody A, Engels K, Gaetje R, von Minckwitz G, Schiffmann S, Grosch S, Geisslinger G, Holtrich U, Karn T, Kaufmann M: Microarray analysis of altered sphingolipid metabolism reveals prognostic significance of sphingosine kinase 1 in breast cancer. Breast Cancer Res Treat 2008, 112:41-52.

85. Ruckhaberle E, Karn T, Rody A, Hanker L, Gatje R, Metzler D, Holtrich U, Kaufmann M: Gene expression of ceramide kinase, galactosyl ceramide synthase and ganglioside GD3 synthase is associated with prognosis in breast cancer. J Cancer Res Clin Oncol 2009, 135:1005-1013.

86. Gu Y, Zhang J, Mi W, Yang J, Han F, Lu X, Yu W: Silencing of GM3 synthase suppresses lung metastasis of murine breast cancer cells. Breast Cancer Res 2008, 10:R1.

87. Goss PE, Baker MA, Carver JP, Dennis JW: Inhibitors of carbohydrate processing: a new class of anticancer agents. Clin Cancer Res 1995, 1:935-944.
88. Paszkiewicz-Gadek A, Porowska H, Lemancewicz D, Wolczynski S, Gindziensk $\mathrm{A}$ : The influence of $\mathrm{N}$ - and O-glycosylation inhibitors on the glycosylation profile of cellular membrane proteins and adhesive properties of carcinoma cell lines. Int J Mol Med 2006, 17:669-674.

89. Tanaka T, Decuzzi P, Cristofanilli M, Sakamoto JH, Tasciotti E, Robertson FM, Ferrari M: Nanotechnology for breast cancer therapy. Biomed Microdevices 2009, 11:49-63.

90. Lo NW, Dennis JW, Lau JT: Overexpression of the alpha2,6-sialyltransferase, ST6Gal I, in a low metastatic variant of a murine lymphoblastoid cell line is associated with appearance of a unique ST6Gal I mRNA. Biochem Biophys Res Commun 1999, 264:619-621.

91. Taniguchi A: Promoter structure and transcriptional regulation of human beta-galactoside alpha2, 3-sialyltransferase genes. Curr Drug Targets 2008, 9:310-316.

92. Glinsky VV, Huflejt ME, Glinsky GV, Deutscher SL, Quinn TP: Effects of Thomsen-Friedenreich antigen-specific peptide P-30 on betagalactoside-mediated homotypic aggregation and adhesion to the endothelium of MDA-MB-435 human breast carcinoma cells. Cancer Res 2000, 60:2584-2588.

93. Heimburg J, Yan J, Morey S, Glinskii OV, Huxley VH, Wild L, Klick R, Roy R, Glinsky VV, Rittenhouse-Olson K: Inhibition of spontaneous breast cancer metastasis by anti-Thomsen-Friedenreich antigen monoclonal antibody JAA-F11. Neoplasia 2006, 8:939-948.

94. Fernandez LE, Alonso DF, Gomez DE, Vazquez AM: Ganglioside-based vaccines and anti-idiotype antibodies for active immunotherapy against cancer. Expert Rev Vaccines 2003, 2:817-823.

95. Vazquez AM, Gabri MR, Hernandez AM, Alonso DF, Beausoleil I, Gomez DE, Perez R: Antitumor properties of an anti-idiotypic monoclonal antibody in relation to N-glycolyl-containing gangliosides. Oncol Rep 2000, 7:751-756.

96. Fuentes D, Avellanet J, Garcia A, Iglesias N, Gabri MR, Alonso DF, Vazquez AM, Perez R, Montero E: Combined therapeutic effect of a monoclonal antiidiotype tumor vaccine against NeuGc-containing gangliosides with chemotherapy in a breast carcinoma model. Breast Cancer Res Treat 2010, 120:379-389.

97. Diaz A, Alfonso M, Alonso R, Saurez G, Troche M, Catala M, Diaz RM, Perez R, Vazquez AM: Immune responses in breast cancer patients immunized with an anti-idiotype antibody mimicking NeuGc-containing gangliosides. Clin Immunol 2003, 107:80-89.

98. Guthmann MD, Castro MA, Cinat G, Venier C, Koliren L, Bitton RJ, Vazquez AM, Fainboim L: Cellular and humoral immune response to N-Glycolyl-GM3 elicited by prolonged immunotherapy with an anti-idiotypic vaccine in high-risk and metastatic breast cancer patients. J Immunother 2006, 29:215-223.

99. Miles D, Papazisis K: Rationale for the clinical development of STn-KLH (Theratope) and anti-MUC-1 vaccines in breast cancer. Clin Breast Cancer 2003, 3(Suppl 4):S134-S138.

100. Slovin SF, Ragupathi G, Fernandez C, Diani M, Jefferson MP, Wilton A, Kelly WK, Morris M, Solit D, Clausen H, Livingston P, Scher HI: A polyvalent vaccine for high-risk prostate patients: 'are more antigens better?' Cancer Immunol Immunother 2007, 56:1921-1930

\section{doi:10.1186/bcr2577}

Cite this article as: Cazet $A$, et al: Tumour-associated carbohydrate antigens in breast cancer. Breast Cancer Research 2010, 12:204. 